\title{
Domain A: Rights and Access to Nature- Land, Water, Seeds and Biodiversity
}

\begin{abstract}
This chapter discusses a seemingly obvious but often underappreciated reality-without secure land tenure as well as access to and control over other elements of natural ecosystems, agroecology specifically, and the sustainable livelihoods of food producers more generally, will be impossible. We review how the access and control over water, ecosystem, cultivated biodiversity, seeds, breeds and soil amongst other aspects of nature enable agroecology. Conversely, we review the disabling conditions in this domain where inadequate and insecure access and tenure rights for various elements of natural ecosystems increase vulnerability, hunger and poverty and undermine agroecology. Insecure rights and access to nature provides little incentive for farmers, communities and territorial networks to invest in long-term agroecological approaches.
\end{abstract}

Keywords Land tenure $\bullet$ Seed systems $\bullet$ Rights $\bullet$ Land reform

Equitable and secure access to, and control over, rights to land and forests, water and fisheries, and seeds and biodiversity are referred to collectively in this book as 'nature'. They are essential to agroecology transformations in every territory. If people do not feel secure about their long-term right to nature, there is little hope for a viable agroecology or for improving wellbeing and sustainable livelihoods. We examine this domain in this chapter.

(C) The Author(s) 2021

C. R. Anderson et al., Agroecology Now!, https://doi.org/10.1007/978-3-030-61315-0_4 
Societies define and regulate the way food producers gain control over and access to land, fisheries and forests through formal and informal tenure systems. These systems determine who can use which resources when, for how long and under what conditions. They may be based on written policies and laws or on unwritten customs and practices (Ostrom 1990) and cover a spectrum from communal to private (Box 4.1).

Secure land tenure and land reform, along with socially protected access to nature, have long shown to be vitally important for smallholder livelihoods, culture, well-being and investment in sustainable agriculture, including agroecology (Lawry et al. 2016). Because subsistence activities depend on nature-based cultural practices, this domain is particularly important for indigenous peoples.

Inadequate or insecure tenure rights to ecosystems, however, may lead to vulnerability, hunger, poverty, conflict and environmental degradation. Insecure tenure offers little incentive for farmers, communities and territorial networks (e.g., farmers' unions and rural social movements) to invest in agroecology for a long term. For indigenous communities in particular, Ellen Woodley et al. (2006) argue that privatization or concessions "by governments or even by Indigenous Peoples themselves to commercial enterprises for logging, mineral and oil exploitation, hydro-electric dams, plantations or designation as national parks frequently destroys their traditional food and agroecological systems and their cultural identity". Woodley adds that changes emerging from such developments in indigenous areas, such as "forced resettlement, compensation, registration of household heads for taxation" or work in extractive industries have not favoured women, eroding their rights, prosperity and status.

Box 4.1 Tenure Arrangements: From Nature Privatized to Nature as Commons (and Beyond)

The classic view of sustainable and productive use of natural resources insisted that the only 'solutions' to stop overexploitation and collapse were two: either privatize them so that owners have an incentive to care for their own 'piece' of the resources or place them under government regulation to restrict their use to sustainable levels (cf. "mutual coercion mutually agreed upon by the majority of the people affected": Hardin 1968). Elinor Ostrom (1990, p. 13) observed that many thinkers have insisted on privatization as the "only" solution. 


\section{Box 4.1 (continued)}

However, analysts have pointed out multiple problems with privatization. For one, it does not address the power differences between those with different abilities to purchase, maintain and defend their ownership (Robbins 2011). Nor does privatization address the equity implications and inequalities that often accompanied "original" ownership claims ("primitive accumulation") or ongoing processes of exploitation and expropriation, "accumulation by dispossession" (Araghi 2008; Robbins 2011). At the same time, privatization and ownership are not any single 'thing' but rather packages of rights (such as access, exclusion, use, disposal). José Vivero-Pol et al. (2018) have critiqued the creep of commodification and privatization in agri-food systems and natural resource systems more broadly, pointing out the necessary diversity of arrangements and negotiations to sustainably and equitably manage natural resources.

The literature on 'the commons'-resources accessed and used by many individuals in common-offers examples of communal ownership and rights that can support agroecology. Insights from such studies and traditional knowledge highlight nuanced, dynamic and sustainable systems of access for land, water, seeds and trees (Ostrom 1990). Analysts have increasingly argued that food and agriculture systems generally should be viewed as systems of commons (ViveroPol et al. 2018).

\section{ENABLING CONDITIONS}

\section{Land}

Much evidence points to secure land tenure as encouraging agroecological approaches and having positive impacts on environmental sustainability, efficiency, equality, productivity, income stability, poverty and hunger reduction (Deininger et al. 2009; Lipton 2009; Higgins et al. 2018). Studies have also revealed causal connections between secure land tenure and investment in agricultural goods and methods that may only bear fruit in the long term, such as planting trees as crops, maintaining and 
improving soil quality, and preventing erosion and other forms of degradation (Fraser 2004; Otsuka 2001).

Land reform-changing laws, regulations or customs regarding land access and ownership - enables secure land tenure. And land reform and agroecological approaches have also proven to be mutually reinforcing in at least some cases, with land reform enabling locally tailored approaches to agroecology and agroecology in turn supporting more sustainable, improved livelihoods for farmers.

Two decades ago, development economist Michael Lipton and colleagues noted that redistributive land reform was a long-established, yet undervalued, policy approach (Lipton et al. 1998, p. 112). Subsequently, in 2009, Lipton noted that land reform-which he defined as "laws with the main goal of reducing poverty by substantially increasing the proportion of farmland controlled by the poor, and thereby their income, power or status"-remained both key and underused in policy. Theoretical and empirical evidence, he wrote, pointed to its positive effects on environmental sustainability, efficiency, equality, productivity and income stability, as well as reducing poverty and hunger.

Globally, experience confirms this statement. In Brazil, what some analysts have called 'ecological' land reform has taken place since the 1980s, with movements like the MST (Landless Rural Workers' Movement) occupying land to support production for local and national consumption rather than export. For example, many MST settlements have focused on growing locally eaten staples rather than crops that do not contribute directly to subsistence, like sugarcane. At the same time, they also work as partners in protection and reforestation of bordering protected forest areas. In other words, many participants in land reform have worked to incorporate social and environmental goals (conservation, subsistence, sufficient income and dignified livelihoods) into planning and implementation of the new settlements resulting from land reform (Chappell et al. 2013; Wittman 2010). Efforts such as those by movement settlers in 14 studied settlements in Mato Grosso to work together to transition to agroecological production and protect forest and river reserves are not a norm in Brazilian land reform settlements. Yet, surveys of about 1500 settlers across 92 settlements in 2000 and 2001 found evidence of increased crop diversity, improved food security and increased self-reported quality of life (Heredia et al. 2016).

Further evidence of enabling dynamics between land reform and agroecology can be seen in the founding of the Latin American Institute of 
Agroecology at an MST settlement (an area where MST members have staked a claim and/or successfully secured redistributed land) and the increased focus on agroecology education within the MST (Schwendler and Thompson 2017). Although agroecology seems a relatively small but growing focus within the landless movement, ${ }^{1}$ land reform does seem to be a crucial enabling factor for agroecology, and vice versa.

Land reform has, however, taken many forms across time and location, and not all have enabled the development of agroecology. Jun Borras (2007) found that the only system bettering the lives of agricultural producers was one that effectively redistributed socio-political power and resources-which is also a bedrock demand of political agroecology and food sovereignty, reemphasizing how land reform and agroecology can be mutually reinforcing. Borras observed that land redistribution actually exists as a spectrum - from arrangements where poor and landless farmers are given access to new land but remain essentially as tenant farmers as they have to pay off the government or previous owner to arrangements where land is expropriated from wealthy landowners with limited or no compensation and the formerly landless are immediately granted full ownership as well as social support to start up production on their new land. Correspondingly, outcomes for agroecology and farmers' well-being and prosperity are always partial and contingent. For example, a systematic review of land reform and its impacts found that secure tenure had a positive impact on "productive and environmentally-beneficial agricultural investments" such as agroecology, as well as empowerment of women, but did not support "links with productivity, access to credit, and income" (Higgins et al. 2018).

The Food and Agriculture Organization of the United Nations' (FAO) Voluntary Guidelines on the Responsible Governance of Tenure of Land, Fisheries and Forests in the Context of National Food Security, also known as VGGT, provides promising guidelines on how to navigate complex land reform processes in ways that maintain or increase social justice. Notably, it emphasizes the importance of recognizing and protecting "all legitimate tenure rights, including customary tenure systems and legitimate customary tenure rights that are not currently protected by law" (Civil Society Mechanism for Relations to the Committee on World Food Security

\footnotetext{
${ }^{1}$ The landless movement involves groups of displaced farmers, rural labourers without their own land, dispossessed indigenous peoples and others attempting to get fairer access to the huge swathes of land in the hands of a small number of wealthy owners.
} 
(CSM) 2016). However, customary tenure systems can themselves leave in place inequalities in social divisions such as gender (Collins 2014). Accordingly, the VGGT suggest multiple pathways for addressing gender inequality, and other issues, through continuous and participatory processes.

In 2012, the Committee on World Food Security (CFS), an intergovernmental and intersectoral forum within the United Nations' system, endorsed the VGGT. Although the guidelines are an international instrument, they have been used extensively within individual countries and subnational territories and communities as well as at the global and regional level (Duncan 2015; Civil Society Mechanism for Relations to the Committee on World Food Security (CSM) 2016).

Complementary principles and parallel suggestions for land tenure governance can be found in documents such as the Voluntary Guidelines for Mainstreaming Biodiversity into Policies, Programmes and National and Regional Plans of Action on Nutrition; for Conservation and Sustainable Use of Crop Wild Relatives and Wild Food Plants; for Seed Policy Formulation; and still other voluntary guidelines around small-scale fisheries and soil. There are as yet fewer academic and civil society analyses of these documents, however, than there are for the VGGT.

\section{Water}

For farmers adopting agroecology, access to water is obviously essentialfor production and for the transformation and preparation of food and fibre within territories. Securing local rights to access, use and control supplies of water also enhances, in turn, local communities' capacity and resources for monitoring and maintaining their broader rights (e.g. "substantive citizenship", as presented by Ribot 2014).

There are many factors determining access to and control over water: property rights, social and political institutions, and cultural and gender norms; the way water is managed, priced and regulated in water basins and at the local level also plays a part. Access may also be affected by factors such as gender, caste, race and occupation. Small-scale producers, vulnerable and marginalized groups and women may find securing access particularly challenging.

Thus, as ample empirical evidence points out, there is a great need for nuanced, culturally and contextually appropriate and inclusive water tenure to enable sustainability (Brisbois and de Loë 2016). Any plans must 
factor in relevant infrastructure and access to relevant sustainable techniques, from rainwater harvesting and drip irrigation to catchment systems, agroforestry and terracing (see, e.g., Giordano et al. 2017).

As with access to other parts of nature, secure access to water can form a virtuous circle with agroecological transitions. The right to water is necessary for food and nutritional security, in which agroecology plays a major role; in turn, agroecological practices can boost water security by improving the way water is conserved and used, thus increasing resilience to water stress (HLPE 2019; Kremen and Miles 2012). For farmers, pastoralists, fishers and indigenous peoples, the ability to experiment with and implement water-conserving agroecological methods ultimately leads to more secure, diversified and resilient local livelihoods.

\section{Seeds and Biodiversity}

Agroecology focuses on indigenous, locally adapted, genetically diverse and traditional crops, so access to such seeds is central to the practice. Rights to such seeds, and decentralized, community-led seed saving, selection and plant breeding, hold great potential for innovations, resilience and livelihoods in agroecology (Halpert and Chappell 2017; Mulvaney 2020). Published research on participatory management of livestock diversity and breeding is limited (Conroy 2008), but considering their promise and the amount of relevant unmet needs in this area, models such as these also need significantly increased resources in terms of supportive policy and monetary and human resources for careful research and implementation. Seeds have received significant attention over the years, but as millions of people depend on livestock for livelihoods and sustenance as well, participatory livestock breeding and diversity efforts have great potential to address unmet needs in breeding for ends related to sustainability, resilience, agroecology and local adaptation (Hoffmann; Wallace 2016, p. \#1029). In fisheries, a substantial literature on common property management regimes has shown the power and potential of such localized and bottom-up schemes (d'Armengol et al. 2018).

To ensure rights to seeds and biodiversity, enterprises, networks and exchanges linked to smallholder seed and livestock breeding must be protected from dominant, 'Western' intellectual property regimes, such as the typical approach taken to patents in the United States and Europe. These regimes are inappropriate in many cases where communities have cooperatively managed their own 'intellectual property' for decades or centuries 
without Western property rights and where requirements like variety's novelty or stability block existing, but effective, approaches and varieties from protection. Along with intellectual property rights (IPR) - the rules and rights that determine who nominally owns genetic material-the legal frameworks that dictate what seeds and livestock breeds can be sold on the market are also of paramount importance. Such globalized, Westerndeveloped and business-focused 'protection' for seeds, germplasm and animal breeds are unsuited to agroecology and need to change in favour of local intellectual property systems (Halpert and Chappell 2017; Forsyth 2013)

Miranda Forsyth (2016) notes that customary systems for protecting intellectual property should not be based on "romantic visions of returning to some imaginary pre-colonial past, but rather on the pragmatic reality that these existing systems are already culturally attuned to promoting goals such as knowledge diffusion and promotion of creativity and innovation". To illustrate this point, she discusses a variety of customary institutions in the Pacific Islands, such as tabu (secrecy regimes), talanoa (oral research and data exchanges), tufuga (traditional crafts guilds) and other biocultural protocols that preserve and protect not just traditional varieties but also traditions and customs, including those governing interactions between humans and nature.

A number of traditional and new concepts and institutions hold potential for protecting access to agricultural biodiversity (whether in livestock, crops, trees or fish) and so enabling agroecological transformation. These include seed sovereignty and the Open Source Seed Initiative (Montenegro de Wit 2017), as well as Livestock Keepers' Rights, fisheries co-management (the joint management of resources by direct users, governments and other actors; see d'Armengol et al. 2018), commonification/decommodification (moving towards commons-based models and away from commodification of agriculture and its products; see Vivero-Pol et al. 2018) and the processes and proposals of the VGGT reviewed above. In general, agroecology demands approaches that not only help sustain the nominal or numerical diversity of crop varieties and livestock but also conserve and enhance high levels of genetic heterogeneity within each crop variety and animal breed. This is because agroecology is based on adaptive responses to diverse 'mosaics' of conditions, including complex, novel and changing ecosystems in specific places, using available genetically heterogeneous plants and animals. As we have seen, this is a circular process. That is, a diversity of agroecological practices can in turn enhance biodiversity (Mulvaney 2020). 
Another key element in this context is the synergy that may develop between farm and wild biodiversity. Research has shown that greater biodiversity on a farm correlates with greater biodiversity in the surrounding environment, and that greater overall (on-farm and wild) biodiversity benefits agriculture (Palomo-Campesino et al. 2018)-for instance, in the thoroughness and efficiency of pollination, leading to greater production and better quality produce, mitigation of and greater resilience to extreme weather events (e.g. rather than attempting to breed a single variety resistant to both drought and waterlogging, a diverse system with varieties that are able to deal with many different circumstances), larger populations and greater diversity of natural predators, healthier soils and decreased erosion. Such holistic systems, with their intersecting biodiversity, have many characteristics of commons (see Box 4.1).

Politically, the approaches to accessing seeds and biodiversity outlined here can be powerful tools for supporting and enabling agroecology. More broadly, localized, participatory 'commons' regimes offer powerful examples too (see Box 4.1), which are particularly well suited to community self-organization for agroecological transformation.

\section{Disabling Conditions}

A number of disabling conditions, or 'lock-ins', pose challenges to those seeking access to ecosystems in the context of agroecological transformations.

\section{Land}

Insecure land tenure and the fragmentation of land through purchase by outside, often corporate, concerns, division during inheritance, expropriation for logging, mining, and other uses, all pose major obstacles to progress on agroecology in many countries. In Uganda, for example, farmers vulnerable to eviction are unlikely to invest in agroecology, or other activities with long-term payoffs, because of the risk of losing access to the land after making the investment (Isgren 2016). And in Bangladesh, while the government has promoted homestead (subsistence) gardening, the fragmentation of residential plots has left many rural people with a plot just big enough for the house. Unable to produce their own food, they depend extensively on the market, where nutritious foods are often unaffordable (Misra 2017). 
Inequality in land tenure is pervasive globally. As measured by the Gini coefficient of inequality, where 0 is perfect equality and $\mathrm{l}$ is perfect inequality, median land ownership in Latin American countries measured was approximately 0.8; only East and Southeastern Asia and sub-Saharan Africa had Gini coefficients of less than 0.5 (Frankema 2005). Western and Northern Africa, the Caribbean, Latin America and some countries in Oceania all had coefficients close to or above 0.65 , the level at which Olivier De Schutter (2010) argues that land reform may be necessary to contribute to the right to food, particularly where landlessness and small plot sizes are linked to significant levels of rural poverty.

These challenges, if combined with undue focus on export-driven policies, can disable attempts to gain land tenure for agroecology. All of these challenges arise "primarily from a dominant model of agricultural development that rewards the most mechanized and capital-intensive farms" and that generally favours large producers (De Schutter 2010), further contributing to the lock-in of the dominant agricultural regime. In urban and peri-urban areas as well, difficulties in accessing or affording land are a significant constraint on urban agroecology's potential (Tornaghi and Dehaene 2020).

Vested interests such as large-scale, wealthy land owners within many countries and international corporate, agricultural and government concerns continue to block reforms such as land redistribution, which have been scaled back or stopped in the face of strong external pressure from the effects of neoliberal capitalism or what has been called "accumulation by dispossession” (Gebara 2018; see also Borras 2007). Corporations and many nation-states see present arrangements as being to their advantage. The private property model concentrates land ownership "in the hands of fewer and fewer people, usually men", and looks to "rule and order" rather than need (Courville 2006). The current economic system (including elite opposition to land reform) is arguably working exactly as it was designed to work - which is not to the benefit of agroecological transition, smallholder farmers or the environment (Holt-Giménez 2017).

Linked to, but extending beyond, land reform and tenure is the issue of large-scale land acquisitions, also known as land grabbing, where corporations or states dispossess and often violently displace peasants from their farms and common lands (Box 4.2). As Matias Margulis et al. (2013) note:

This global land rush is characterized by transnational and domestic corporate investors, governments, and local elites taking control over large quantities of land (and its minerals and water) to produce food, feed, biofuel, and 


\section{Box 4.2 Agroecology as an Organizing Force Against Land and Water Grabbing}

Large-scale acquisition of resources, particularly land and groundwater grabbing, is threatening farmer societies in Senegal. It sweeps away all the gains achieved among rural communities who are working hard to advance agroecology. Over the past decade, these Senegalese organizations have developed a joint vision for viable and sustainable production systems and community-led land governance. In 2010 the government included the concept of 'healthy and sustainable agriculture' in its agricultural policy and earmarked a specific budget for it.

However, progress was disrupted when the same government pushed for the establishment of multinational corporations in these territories, arguing that it was the only way towards food security. This transformed family farmers into farm workers on their own land while putting the environment at risk. While only 6 cases of land grabbing (totalling 168,964 hectares) were recorded in Senegal between 2000 and 2007, there were 30 cases recorded between 2008 and 2011 , accounting for a staggering 630,122 hectares. This is an unprecedented increase, and it sparked outrage and led to protests.

Existing agro-industrial facilities and mining companies have often failed to carry out environmental studies, particularly with respect to the contamination of water with chemicals and other effects on water resources. Depletion of various layers of groundwater has occurred as a result of excessive water extraction by agribusinesses. Early signs of conflict over water have emerged precisely in the areas where agroecology has taken root: Niayes, Keur Moussa, the lower valley/Lac de Guiers and the Petite Cote.

For years, farmers' organizations and their allies in Senegal have combated the co-optation of their resources through awareness raising, calls for mobilization, research, training and advocacy. The basic principle defended by farmers is that land and other resources must be in the hands of the communities and that an agricultural policy must be based on a system of financing that is favourable to family farming. Farmers' organizations developed their own policy proposals, pointing out that land must be considered along with access to nature more broadly. They called on the government to implement 


\section{Box 4.1 (continued)}

an integrated rural development policy to achieve food sovereignty. As a result of this advocacy work, the National Commission for Land Reform (CNRF) decided to integrate civil society organizations into its steering committee and to stop promoting the commercialization of land.

These technical, organizational and political results encourage farmers' groups to pursue their mission of supporting rural families in reclaiming governance of their land and the implementation of integrated development strategies that can lead them towards food sovereignty. The situation in Senegal demonstrates that agroecology can be a strong organizational force for the protection of access to nature.

Source: Brun (2018)

other industrial commodities for the international or domestic markets. Such land deals are often associated with very low levels of transparency, consultation, and respect for the rights of local communities living off the land.

Often taking place under the guise of investments for development, land and water grabs are arguably the opposite of much-needed land reforms for agroecology.

\section{Water}

Inevitably, issues with control of water overlap with those related to control of land. Excessive control by private interests and denial of access to local communities (Swyngedouw 2005; HLPE 2015) block the possibilities offered by agroecology. As Howard Mann and Carin Smaller (2010) wrote, "The current land purchase and lease arrangements are largely about shifting land and water uses from local farming to essentially long-distance farming to meet home state food and energy needs."

Such a switch militates against the benefits and ethos of agroecology, which emphasize strengthening local governance and local production 
systems. In 2014, social movements presented a declaration, Rights to Water and Land, a Common Struggle (World Forum for Alternatives 2014) [https://commonstransition.org/rights-to-water-and-land-acommon-struggle/>], at the World Social Forum in Tunis. This recognizes the "essential linkage between [their] struggles, given the inextricable nature of land and water grabbing" and states that "the scarcity underpinning the water, land and food crises is not a given; it is a political, geostrategic and financial construct".

\section{Seeds and Biodiversity}

Big industrial agriculture and the prevailing food system (the corporate food regime) depend on industrial inputs and processing. For over two decades, the markets for these products and processes have become increasingly concentrated and consolidated, a process that locks industrial methods into agriculture and disables access to seeds and biodiversity.

For example, the commercial seed market is now nearly dominated by just two firms (Howard 2016). High degrees of concentration and consolidation are also seen in markets for livestock, particularly 'broiling' chickens, turkeys, pigs and beef cattle (Hendrickson et al. 2017). Diversity within commercial livestock appears to have suffered as a result, with "only two companies providing layer hen genetics and four providing those for broilers": significant volumes of global egg and broiler production are thus now designed to meet industrial needs (Gura 2007). This trend has been called "one of the most pressing concerns" about the industrialization of agriculture (Hendrickson et al. 2017). Narrowing diversity, both within and among seeds and breeds, is hugely problematic for agroecologists, as corporate concerns extend their grasp around the world, and traditional seed-and breed-saving methods and networks are marginalized or even rendered illegal.

We discussed earlier international intellectual property regimes based primarily on legalistic Western approaches. These are arguably ill-suited to help farmers adapt to climate change and extreme weather events, particularly as they tend towards doubling down on failed strategies by seeking to produce monocultures of drought-resistant seeds-seeds that then do not have the genetic variation or the legal entitlements necessary for them to adapt and respond to other foreseen or 
unforeseen challenges, from waterlogging to novel pests (Halpert and Chappell 2017). The control of so much of the seed supply by a handful of international corporations stifles farmers' innovation by centralizing research and drastically restricting farmer experimentation and variety development through intellectual property 'protections'. This limits their ability to adapt seeds to local conditions by locking useful traits and varieties behind intellectual property, buying up or undercutting local seed systems, and promoting 'faddism' - or in the words of some analysts, draining more from the pool of knowledge (through patents) than they are giving back (Halpert and Chappell 2017; Stone et al. 2014). Similar problems arise in livestock rearing (Wallace 2016; Gura 2007). Taken together, these trends constitute a threat to the practice of viable agroecology.

\section{REFERENCES}

Araghi, F. (2008). The Invisible Hand and the Visible Foot: Peasants, Dispossession and Globalization. In A. H. A.-L. C. Kay (Ed.), Peasants and Globalisation: Political Economy, Rural Transformation and the Agrarian Question (pp. 111-147). London: Routledge.

Borras, S. M., Jr. (2007). Pro-poor Land Reform: A Critique. Ottawa: University of Ottawa Press.

Brisbois, M. C., \& de Loë, R. C. (2016). Power in Collaborative Approaches to Governance for Water: A Systematic Review. Society o Natural Resources, $29(7), 775-790$.

Brun, L. (2018). Landgrabbing Threatens Agroecology in Senegal. Farming Matters.

Chappell, M. J., Wittman, H., Bacon, C. M., Ferguson, B. G., Barrios, L. G., Barrios, R. G., et al. (2013). Food Sovereignty: An Alternative Paradigm for Poverty Reduction and Biodiversity Conservation in Latin America. Fl000Res, 2, 235.

Civil Society Mechanism for Relations to the Committee on World Food Security (CSM). (2016). Synthesis Report on Civil Society Experiences Regarding Use and Implementation of the Tenure Guidelines and the Challenge of Monitoring CFS Decisions. Rome.

Collins, A. M. (2014). Governing the Global Land Grab: What Role for Gender in the Voluntary Guidelines and the Principles for Responsible Investment? Globalizations, 11(2), 189-203. 
Conroy, C. (2008). Livestock, Livelihoods, and Innovation. In S. S. S. B. Pound (Ed.), Agricultural Systems: Agroecology and Rural Innovation for Development (pp. 253-280). Burlington, MA: Elsevier.

Courville, M. P. R. (2006). Introduction and Overview: The Resurgence of Agrarian Reform in the Twenty-first Century. In R. C. P. M. C. P. M. Rosset (Ed.), Promised Land: Competing Visions of Agrarian Reform (pp. 3-22). New York: Food First Books/CDS.

d'Armengol, L., Castillo, M. P., Ruiz-Mallén, I., \& Corbera, E. (2018). A Systematic Review of Co-managed Small-Scale Fisheries: Social Diversity and Adaptive Management Improve Outcomes. Global Environmental Change, $52,212-225$.

De Schutter, O. (2010). The Right to Food: Interim Report of the Special Rapporteur. New York, NY: The United Nations.

Deininger, K., Jin, S., \& Nagarajan, H. K. (2009). Land Reforms, Poverty Reduction, and Economic Growth: Evidence from India. The Journal of Development Studies, 45(4), 496-521.

Duncan, J. (2015). Global Food Security Governance: Civil Society Engagement in the Reformed Committee on World Food Security. Oxon: Routledge.

Forsyth, M. (2016). Making the Case for a Pluralistic Approach to Intellectual Property Regulation in Developing Countries. Queen Mary Journal of Intellectual Property, 6(1), 3-26.

Forsyth, M. F. S. (2013). Intellectual Property and Food Security in Least Developed Countries. Third World Quarterly, 34(3), 516-533.

Frankema, E. H. (2005). The Colonial Origins of Inequality: Exploring the Causes and Consequences of Land Distribution. Discussion papers//Ibero America Institute for Economic Research.

Fraser, E. D. G. (2004). Land Tenure and Agricultural Management: Soil Conservation on Rented and Owned Fields in Southwest British Columbia. Agriculture and Human Values, 21(1), 73-79.

Gebara, M. F. (2018). Tenure Reforms in Indigenous Lands: Decentralized Forest Management or Illegalism? Current Opinion in Environmental Sustainability, $32,60-67$.

Giordano, M., Turral, H., Scheierling, S. M., Tréguer, D. O., \& McCornick, P. G. (2017). Beyond "More Crop per Drop": Evolving Thinking on Agricultural Water Productivity. Colombo, Sri Lanka: IWMI Research Report No. 169.

Gura, S. (2007). Livestock Genetics Companies: Concentration and Proprietary Strategies of an Emerging Power in the Global Food Economy. Ober-Ramstadt, Germany: League for Pastoral Peoples and Endogenous Livestock Development. 
Halpert, M.-T., \& Chappell, M. J. (2017). Prima facie reasons to question enclosed intellectual property regimes and favor open-source regimes for germplasm [version 1; peer review: 3 approved, 1 approved with reservations]. F1000Research, 6:284. https://doi.org/10.12688/f1000research.10497.1.

Hardin, G. (1968). The Tragedy of the Commons. Science, 162(3859), 1243-1248.

Hendrickson, M. K., Howard, P. H., \& Constance, D. H. (2017). Power, Food and Agriculture: Implications for Farmers, Consumers and Communities. Division of Applied Social Sciences Working Papers, University of Missouri College of Agriculture, Food \& Natural Resources.

Heredia, B., Medeiros, L., Palmeira, M., Cintrão, R., \& Pereira Leite, S. (2016). Regional Impacts of Land Reform in Brazil. In R. C. P. P. M. Rosset \& M. Courville (Eds.), Promised Land: Competing Visions of Agrarian Reform (pp. 277-300). New York: Food First Books/CDS.

Higgins, D., Balint, T., Liversage, H., \& Winters, P. (2018). Investigating the Impacts of Increased Rural Land Tenure Security: A Systematic Review of the Evidence. Journal of Rural Studies, 61, 34-62.

HLPE. (2015). Water for Food Security and Nutrition: A Report by the High Level Panel of Experts on Food Security and Nutrition of the Committee on World Food Security. Rome: HLPE.

HLPE. (2019). Agroecological and Other Innovative Approaches for Sustainable Agriculture and Food Systems That Enhance Food Security and Nutrition. Rome: High Level Panel of Experts on Food Security and Nutrition of the Committee on World Food Security.

Holt-Giménez, E. (2017). A Foodie's Guide to Capitalism: Understanding the Political Economy of What We Eat. New York: Monthly Review Press and Food First Books.

Howard, P. H. (2016). Concentration and Power in the Food System: Who Controls What We Eat? London: Bloomsbury Academic Publishing.

Isgren, E. (2016). No Quick Fixes: Four Interacting Constraints to Advancing Agroecology in Uganda. International Journal of Agricultural Sustainability, 14(4), 428-447.

Kremen, C., \& Miles, A. (2012). Ecosystem Services in Biologically Diversified Versus Conventional Farming Systems: Benefits, Externalities, and Trade-offs. Ecology and Society, 17(4), 40.

Lawry, S., Samii, C., Hall, R., Leopold, A., Hornby, D., \& Mtero, F. (2016). The Impact of Land Property Rights Interventions on Investment and Agricultural Productivity in Developing Countries: A Systematic Review. Journal of Development Effectiveness, 9(1), 61-81.

Lipton, M. (2009). Land Reform in Developing Countries: Property Rights and Property Wrongs. London and New York: Routledge. 
Lipton, M., Yaqub, S., \& Darbellay, E. (1998). Successes in Anti-poverty. Geneva: International Labor Organization.

Mann, H., \& Smaller, C. (2010). Foreign Land Purchases for Agriculture: What Impact on Sustainable Development. Sustainable Development Innovation Brief, 8, 1-8.

Margulis, M. E., McKeon, N., \& Borras, S. M. (2013). Land Grabbing and Global Governance: Critical Perspectives. Globalizations, 10(1), 1-23.

Misra, M. (2017). Moving Away from Technocratic Framing: Agroecology and Food Sovereignty as Possible Alternatives to Alleviate Rural Malnutrition in Bangladesh. Agriculture and Human Values, 35, 473-487.

Montenegro de Wit, M. (2017). Beating the Bounds: How Does 'open source' Become a Seed Commons? The Journal of Peasant Studies, 46(1), 44-79.

Mulvaney, P. (2020). Sustaining Agricultural Biodiversity and Heterogeneous Seeds for Responsible Agriculture and Food Systems. In A. Kassam \& L. Kassam (Eds.), Rethinking Food and Agriculture. Elsevier.

Ostrom, E. (1990). Governing the Commons: The Evolution of Institutions for Collective Action. Cambridge University Press.

Otsuka, K. P. F. M. (2001). Land Tenure and Natural Resource Management: A Comparative Study of Agrarian Communities in Asia and Africa. International Food Policy Research Institute (IFPRI): Baltimore and London.

Palomo-Campesino, S., González, J., \& García-Llorente, M. (2018). Exploring the Connections between Agroecological Practices and Ecosystem Services: A Systematic Literature Review. Sustainability, 10(12), 4339.

Ribot, J. (2014). Cause and Response: Vulnerability and Climate in the Anthropocene. The Journal of Peasant Studies, 41(5), 667-705.

Robbins, P. (2011). Political Ecology: A Critical Introduction (Vol. 16). John Wiley \& Sons.

Schwendler, S. F., \& Thompson, L. A. (2017). An Education in Gender and Agroecology in Brazil's Landless Rural Workers' Movement. Gender and Education, 29(1), 100-114.

Stone, G. D., Flachs, A., \& Diepenbrock, C. (2014). Rhythms of the Herd: Long Term Dynamics in seed choice by Indian farmers. Technology in Society, 36, 26-38.

Swyngedouw, E. (2005). Dispossessing H2O: The Contested Terrain of Water Privatization. Capitalism Nature Socialism, 16(1), 81-98.

Tornaghi, C., \& Dehaene, M. (2020). The Prefigurative Power of Urban Political Agroecology: Rethinking the Urbanisms of Agroecological Transitions for Food System Transformation. Agroecology and Sustainable Food Systems, 44:5, 594-610, https://doi.org/10.1080/21683565.2019.1680593

Vivero-Pol, J. L., Ferrando, T., De Schutter, O., \& Mattei, U. (2018). Routledge Handbook of Food as a Commons: Routledge.

Wallace, R. (2016). Big Farms Make Big Flu: Dispatches on Influenza, Agribusiness, and the Nature of Science. New York, NY: Monthly Review Press. 
Wittman, H. (2010). Agrarian Reform and the Environment: Fostering Ecological Citizenship in Mato Grosso, Brazil. Canadian Journal of Development Studies/ Revue canadienne d'études du développement, 29(3-4), 281-298.

Woodley, E., Crowley, E., de Pryck, J. D., \& Carmen, A. (2006). Cultural Indicators of Indigenous Peoples' Food and Agro-Ecological Systems. SARD Initiative Commissioned by FAO and the International India Treaty Council. World Forum for Alternatives. (2014). Rights to Water and Land, a Common Struggle.

Open Access This chapter is licensed under the terms of the Creative Commons Attribution 4.0 International License (http://creativecommons.org/licenses/ by $/ 4.0 /$ ), which permits use, sharing, adaptation, distribution and reproduction in any medium or format, as long as you give appropriate credit to the original author(s) and the source, provide a link to the Creative Commons licence and indicate if changes were made.

The images or other third party material in this chapter are included in the chapter's Creative Commons licence, unless indicated otherwise in a credit line to the material. If material is not included in the chapter's Creative Commons licence and your intended use is not permitted by statutory regulation or exceeds the permitted use, you will need to obtain permission directly from the copyright holder.

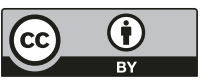

